\title{
Quantifying microbial methane oxidation efficiencies in two experimental landfill biocovers using stable isotopes
}

Cabral, A.R. ${ }^{1,}{ }^{*}$, Capanema, M. A. ${ }^{1}$, Gebert, J. ${ }^{2}$, Moreira, J.F. ${ }^{1}$ and Jugnia, L.B. ${ }^{3}$

${ }^{1}$ Dept. Civil Eng., Faculty of Eng., Univ. de Sherbrooke, Sherbrooke, QC, Canada, J1K 2R1

${ }^{2}$ University of Hamburg, Institute of Soil Science, Allende-Platz 2, 20146 Hamburg, Germany

${ }^{3}$ Biotechnology Research Institute, 6100, Royalmount Ave., Montreal, QC, Canada, H4P 2R2

* Corresponding author: Alexandre.cabral@usherbrooke.ca, +1 819-821-7906; +1-819-821-7974 (fax)

\begin{abstract}
Stable isotope analyses were performed on gas samples collected within two instrumented biocovers, with the goal of evaluating $\mathrm{CH}_{4}$ oxidation efficiencies $\left(f_{0}\right)$. In each of the biocovers, gas probes were installed at four locations and at several depths. One of the biocovers was fed with biogas directly from the waste mass, whereas the other was fed through a gas distribution system that allowed monitoring of biogas fluxes. While the $f_{0}$ values obtained at a depth of $0.1 \mathrm{~m}$ were low (between 0.0 and $25.2 \%$ ) for profiles with poor aeration, they were high for profiles with better aeration, reaching $89.7 \%$. Several interrelated factors affecting aeration seem to be influencing $f_{0}$, including the degree of water saturation, the magnitude of the biogas flux, and the temperature within the substrate. Low $f_{0}$ values do not mean necessarily that little $\mathrm{CH}_{4}$ was oxidized. In fact, in certain cases where the $\mathrm{CH}_{4}$ loading was high, the absolute amount of $\mathrm{CH}_{4}$ oxidized was quite high and comparable to the rate of $\mathrm{CH}_{4}$ oxidation for cases with low $\mathrm{CH}_{4}$ loading and high $f_{0}$. For the experimental biocover for which the $\mathrm{CH}_{4}$ loading was known, the oxidation efficiency obtained using stable isotopes $\left(f_{0}=55.67 \%\right.$ for samples taken inside flux chambers) was compared to the value obtained by mass balance $\left(f_{0}=70.0 \%\right)$. Several factors can explain this discrepancy, including: the high sensitivity of $f_{0}$ to slight changes in the isotopic fractionation factor for bacterial oxidation, $\alpha_{\mathrm{ox}}$, uncertainties related to mass flow meter readings and to the static chamber method.
\end{abstract}

Keywords: methane oxidation, biocovers, carbon stable isotopes, landfill.

\author{
Water Air Soil Pollut (2010) 209:157-172 \\ DOI $10.1007 / \mathrm{s} 11270-009-0188-4$
}

Received: 26 March 2009/Accepted: 31 August 2009/Published online: 30 September 2009 


\section{INTRODUCTION}

Methane $\left(\mathrm{CH}_{4}\right)$ is a greenhouse gas with an infrared activity 25 times that of $\mathrm{CO}_{2}$ (IPCC 2007) and its atmospheric concentration is increasing at a rate of $0.6 \%$ per year (IPCC 2001). Landfills represent an important source of $\mathrm{CH}_{4}$ emissions and, according to several sources (e.g. Bogner and Matthews 2003; De Visscher et al. 2004; Stern et al. 2007; Chanton et al. 2008), their contribution to the global $\mathrm{CH}_{4}$ emissions may vary from 3 to $10 \%$. Therefore, management practices that could help reduce emissions from landfills are of great importance in connection with the atmospheric $\mathrm{CH}_{4}$ budget. Gas extraction systems, which are now widely adopted in the developed world, are considered the principal means of achieving such reductions. However, gas collection systems are not $100 \%$ efficient; indeed, it has been reported that even at sites with gas collection systems, significant amounts of biogas can still escape as fugitive emissions (e.g. Spokas et al. 2006; Börjesson et al. 2007).

According to the Working Group III of the Intergovernmental Panel on Climate Change, one promising management strategy to reduce emissions from landfills is the installation of a biocover as part of the final cover system (IPCC 2007; Table SPM 3). When a final cover is engineered to optimize the growth and activity of the methanotrophic bacteria, it becomes a passive methane oxidation biocover (PMOB). In $\mathrm{PMOBs} \mathrm{CH}_{4}$ reduction is regulated by methanotrophic bacteria that develop in the aerobic zone near the surface. The microbial oxidation of methane for the abatement of landfill methane emissions is not only applicable as a complement to gas extraction, but is also suited to treat residual emissions during aftercare or low calorific emissions from wastes that have a low gas generation rate.

Methanotrophs in landfill covers or biofilters are capable of converting $\mathrm{CH}_{4}$ to $\mathrm{CO}_{2}$ and biomass in the presence of atmospheric $\mathrm{O}_{2}$ (e.g. Boeckx et al. 1996; Humer and Lechner 1999; Boeckx and Van Cleemput 2000; Hilger and Humer 2003; Gebert and Gröngröft 2006; Stern et al. 2007). The process of microbial oxidation is influenced by several factors, including, among others, the temperature within the cover, the diffusivity of the cover material and the magnitude of biogas flux. The latter partly depends on the differential pressure between the waste mass and the atmosphere that also partly controls the availability of $\mathrm{O}_{2}$, and the air-filled porosity, which also depends on the amount of water infiltration through the top cover.

Despite the promising future of biocovers, the reliability of methods to estimate $\mathrm{CH}_{4}$ oxidation efficiency of biocovers in the field remains a problem. It is indeed difficult to estimate efficiencies without knowledge of the $\mathrm{CH}_{4}$ fluxes reaching the base of a cover and leaving it, moreover when emissions may span over 7 orders of magnitude (Bogner et al. 1997), and important variations in the magnitude of emissions may be found within the same landfill (Czepiel et al. 1996; Scheutz et al. 2003). A technique that has been recently employed in several field studies 
estimates $\mathrm{CH}_{4}$ oxidation efficiency in landfill covers based on changes in the ratio of two stable carbon isotopes, namely ${ }^{13} \mathrm{C}$ and ${ }^{12} \mathrm{C}$ (Liptay et al. 1998; Chanton and Liptay 2000; De Visscher et al. 2004; Chanton et al. 2008). While ${ }^{12} \mathrm{C}$ is $99 \%$ abundant, ${ }^{13} \mathrm{C}$ responds for the remaining $1 \%$.

This paper presents the results obtained from the stable isotope analysis performed on gas samples collected during the 2007 monitoring campaign of two PMOBs installed at the St-Nicéphore landfill, Quebec, Canada, a waste disposal facility covering approximately 65 hectares that receives mainly domestic waste. The goal was to estimate the biotic methane oxidation efficiencies of the two PMOBs. Gas samples were frequently taken at several locations and depths within the PMOBs. For clarity, the main design characteristics of the PMOBs and the instrumentation installed are described.

\section{BACKGROUND}

The carbon stable isotope composition is expressed as follows (e.g. Chanton et al. 1999):

$$
\delta^{13} C(\%)=\left[\left(\frac{R_{\text {sample }}}{R_{\text {standard }}}\right)-1\right] \times 1000(1)
$$

where $R_{\text {sample }}$ is the ${ }^{13} \mathrm{C} /{ }^{12} \mathrm{C}$ ratio of the sample and $R_{\text {standard }}$ is the ${ }^{13} \mathrm{C} /{ }^{12} \mathrm{C}$ ratio of the reference standard VPDB (Vienna Peedee Belemnite; $\left.R_{\text {standard }}=0.01124\right)$.

Studies using methanotrophic cultures have shown that the lighter isotope ${ }^{12} \mathrm{C}$ is oxidized more rapidly than the heavier isotope ${ }^{13} \mathrm{C}$, (Chanton and Liptay 2000; De Visscher et al. 2004). As a result, changes in isotope composition occur when methane is oxidized, altering the isotope ratio. Indeed, $\delta^{13} \mathrm{C}$ values of $\mathrm{CH}_{4}$ produced in the deepest zone of the landfill profile are typically between -50 and $-61 \%$, and the $\delta^{13} \mathrm{C}$ values of emitted $\mathrm{CH}_{4}$ are generally between -30 and $-50 \%$ (Chanton et al. 1999). Knowledge of $\delta^{13} \mathrm{C}$ values of the $\mathrm{CH}_{4}$ produced and emitted allows calculating the fraction of methane that is oxidized when fugitive emissions of biogas migrate through the top cover (De Visscher et al. 2004). The percentage of $\mathrm{CH}_{4}$ oxidized (or oxidation efficiency, $f_{0}$ ) is determined by the following equation (taken from Abichou et al. 2006a):

$$
f_{0}=0.1 \times \frac{\delta_{\mathrm{E}}-\delta_{\mathrm{A}}}{\alpha_{\mathrm{ox}}-\alpha_{\text {trans }}}
$$


where $\delta_{\mathrm{A}}$ is the $\delta^{13} \mathrm{C}$ value of the anoxic zone; $\delta_{\mathrm{E}}$ is the $\delta^{13} \mathrm{C}$ value of emitted $\mathrm{CH}_{4} ; \alpha_{\mathrm{ox}}$ is the isotopic fractionation factor for bacterial oxidation; and $\alpha_{\text {trans }}$ is the isotopic fractionation factor associated with gas transport.

The fractionation factor for microbial oxidation $\alpha_{o x}$ can be obtained empirically (Liptay et al. 1998; De Visscher et al. 2004). Previous studies pertaining to landfill emissions reported different values of $\alpha_{\mathrm{ox}}$, some of which are summarized in Table 1 (with the associated temperatures prevailing when the samples were taken). The variation of soil temperature modifies the fractionation factor value and, therefore, the calculated methane oxidation efficiency. Tyler et al. (1994) presented a temperature-dependent variation of $\alpha_{\mathrm{ox}}=0.00046 / \mathrm{K}$, with increasing temperatures causing a decrease in $\alpha_{o x}$, thus an increase in $f_{0}$. In a seasonal variation study, Chanton and Liptay (2000) obtained the following dependence relationship: $\alpha_{o x}=0.000435 /{ }^{\circ} \mathrm{C}$, where $\alpha_{\mathrm{ox}}$ varied between 1.025 (at $35^{\circ} \mathrm{C}$ ) and $1.049\left(\right.$ at $\left.8^{\circ} \mathrm{C}\right)$, with the latter being among the greatest values found in the literature.

According to the study by Chanton and Liptay (2000), $\alpha_{o x}$ does not vary as a function of soil texture. Liptay et al. (1998) also reported that differences between clayey and sandy soils didn't affect the $\alpha_{o x}$ value, despite varying oxidation efficiencies. Tyler et al. (1994) observed that moisture content affected the $\alpha_{o x}$ value.

The isotopic fractionation factor associated with gas transport $\left(\alpha_{\text {trans }}\right)$ is assumed to be 1.0 , which supposes that $\mathrm{CH}_{4}$ transport across the PMOB is dominated by advection (Liptay et al. 1998; Abichou et al. 2006b; Stern et al. 2007), a process that does not cause isotopic fractionation (Liptay et al. 1998). Recent laboratory experiments by De Visscher et al. (2004) have shown that this approach can underestimate $\mathrm{CH}_{4}$ oxidation by not taking into account diffusive flux, which can play a significant role in gas transport. If diffusive transport becomes important, then $\alpha_{\text {trans }}$ would be greater than 1. However, several authors (including De Visscher et al. 2004; and Stern et al. 2007) cite the works of Czepiel et al. (1996; 2003) who claim that the assumption of a preponderance of advective flux is supported by observations of a strong negative relationship between $\mathrm{CH}_{4}$ emission and atmospheric pressure at several landfills. This is particularly true for landfill sites without gas collection systems.

\section{Materials and Methods}

\section{Experimental plots}

Three experimental plots measuring $2.75 \mathrm{~m}(\mathrm{~W}) \times 9.75 \mathrm{~m}(\mathrm{~L})$ were constructed with a slope of $3.5 \%$, in the middle of an already capped area of the St-Nicéphore landfill. The final cover in this area was constructed with a 
thick (almost $3 \mathrm{~m}$ in certain areas) layer of silt placed directly on the waste mass (as required by law). In this paper, only details pertaining to two PMOBs, namely PMOB-1 and PMOB-3B, are presented.

PMOB-1 included a $0.80 \mathrm{~m}$ thick layer of substrate underlain by a $0.10 \mathrm{~m}$ thick transitional layer consisting of 6.4-mm clean gravel and a 2.0- $\mathrm{m}$ thick gas distribution layer (GDL) consisting of 12.7-mm clean gravel. This plot was fed directly by biogas coming from the 3.5-year old buried waste mass (Fig. 1). As a result, it was not possible to control (or to obtain) the upward flux of biogas. The substrate layer consisted of a mixture of sand and compost, composed of 5 volumes of compost (before sieving) and 1 volume of coarse sand $\left(\mathrm{D}_{10}=0.07 \mathrm{~mm} ; \mathrm{D}_{85}=0.8 \mathrm{~mm}\right)$. More details on the compost and the mixture can be found in Jugnia et al. (2008). The substrate layer was placed in four $0.2-\mathrm{m}$ layers and compacted with a vibrating plate to obtain layers with an average density of $8.4 \mathrm{kN} \mathrm{m}^{-3}$ and total porosity $(\mathrm{n})$ equal to 0.63 . The specific density of the solids $\left(\mathrm{G}_{\mathrm{s}}\right)$ of the sand-compost mixture is equal to 22.5 $\mathrm{kN} \mathrm{m}^{-3}$.

PMOB-3B (Fig. 2) was constructed using a coarser substrate that resulted from mixing one volume of the same material used as substrate in PMOB-1 with one volume of 6.4-mm gravel. The $0.3-\mathrm{m}$ thick substrate was compacted to a density of $14.0 \mathrm{kN} \mathrm{m}^{-3}$ and total porosity equal to 0.48 . The GDL included $0.10 \mathrm{~m}$ of $6.4-\mathrm{mm}$ clean gravel as a transitional layer and $0.80 \mathrm{~m}$ of 12.7-mm clean gravel layer. Contrary to PMOB-1, PMOB-3B was lined with a 1mm thick HDPE geomembrane (GM), protected against tearing by a geotextile sheet. This completely isolated this experimental plot from the existing silty cover and the waste mass. PMOB-3B was fed with biogas from a well installed exclusively for this study. The amount of biogas fed into the system was controlled by means of a valve and the flow could be monitored by a mass flow meter connected to a data acquisition system. A drainage system was installed at the lowest point to evacuate infiltrating waters.

The walls around each of the two PMOBs were thermally shielded from the outside environment by $0.15-\mathrm{m}$ thick polystyrene panels. The goal was to prevent lateral migration of moisture due to thermal gradients, which could lead to preferential flow paths. Temperature sensors (TMC20-HD, from Onset), connected to a data acquisition system (HOBO U12, from Onset) and gas probes (aluminum tubes with an inner diameter of $10 \mathrm{~mm}$ that were capped at the top end with a septum) were permanently installed at 4 separate downgradient points and at 4 different depths (6 depths in the case of gas probes) in each profile (Fig. 3), making up for a total of 48 gas probes and 32 temperature sensors for the two PMOBs. Tensiometers (Low Tension Irrometer, from Irrometer Company) and water content sensors (EC-5, from Decagon) were also installed and connected to data acquisition systems, allowing for the determination of the degree of saturation. The temperature and water content probes were 
connected to data loggers. Meteorological data, including air temperature, precipitation, atmospheric pressure and wind speed were continuously recorded by a weather station installed near the experimental plots.

\section{Gas analyses}

For each gas probe in a profile, gas samples were taken on a weekly basis. The equivalent to the volume of the aluminum tubes was initially purged using the same syringe that one hour later was again introduced through the septum to collect the gas sample. The volumetric concentrations of $\mathrm{CH}_{4}, \mathrm{CO}_{2}$ and $\mathrm{O}_{2}$ in the collected samples were obtained using a portable landfill gas analyser (Portable Gas Meter, Columbus Instruments, OH) equipped with infrared sensors able to detect $\mathrm{CO}_{2}$ and $\mathrm{CH}_{4}$. It also has an electrochemical sensor able to detect the volumetric concentration of $\mathrm{O}_{2}$.

In mid summer of 2007, samples were also collected at a depth of $0.05 \mathrm{~m}$ using a specially designed gas probe that was manually inserted in the soil at every sampling date. Due to the small volume of biogas collected at this depth, gas samples were stored in a vacutainer serum tube and analysed within 24 hours in the laboratory using a gas chromatograph (Agilent 3000A Micro GC, equipped with a TCD detector and two columns, Molsieve for $\mathrm{CH}_{4}$ and $\mathrm{O}_{2}$ and Plot $\mathrm{Q}$ for $\mathrm{CO}_{2}$ ).

In order to draw concentration profiles, the $\mathrm{CO}_{2}$ and $\mathrm{CH}_{4}$ concentrations at the surface were assumed to be nil due to dilution with atmospheric air (which does not mean that the $\mathrm{CH}_{4}$ surface fluxes were exactly equal to zero). The $\mathrm{O}_{2}$ volumetric concentration in the air, at the surface, was assumed to be equal to $20.9 \%$. The $\mathrm{N}_{2}$ concentrations were not obtained by direct measurement, but calculated as the difference between $100 \%$ and the sum of the concentrations of the three other gases $\left(\mathrm{CO}_{2}, \mathrm{O}_{2}\right.$ and $\left.\mathrm{CH}_{4}\right)$. As compared to $\mathrm{O}_{2}, \mathrm{~N}_{2}$ is more relevant in indicating the aeration level, because it is neither consumed by oxidation near the surface nor by soil respiration. This was calculated for each depth within the several profiles analysed.

\section{Stable isotope analyses}

Samples for stable isotope analyses were taken at selected dates and locations in order to study oxidation efficiencies of four types of profiles, which are presented in the Results section. Samples were usually taken from the deepest gas sampling tube - that contains raw landfill gas - and from the top-most gas tube $(0.10 \mathrm{~m}$; in one case, $0.05 \mathrm{~m})$. For 3 selected profiles, samples were also taken from approximately mid-depth $(0.3$ or $0.4 \mathrm{~m})$ of the substrate layer. 
For all the selected dates, a sample for stable isotope analysis was taken during surface flux measurements, which were performed on a weekly basis at several locations at each of the plots, following the static chamber method, as described by Fécil et al. (2003). In the present study, the sample was taken while the concentration within the chamber was still increasing.

Isotope analyses were performed at the Delta-Lab (Geological Survey of Canada, GSC-Quebec). The GC-CIRMS system consists of a HP 5890 Series II Gas Chromatograph (GC) coupled with a VG Prism III Isotopic Ratio Mass Spectrometer (IRMS) via a combustion interface VG Isochrom II. The GC column was a PoraPlot Q (Varian, CP-7551) plot-fused silica column $(25 \mathrm{~m}, 0.32 \mathrm{~mm})$. The results obtained were normalized (re-calculated versus VPDB) using three internal gas standards. Two of them (BISO-1, HISO-1) were mixtures of $0.25 \%$ of methane and air. These were calibrated versus VPDB at the University of Victoria, BC. The third gas, $\mathrm{CO}_{2}$ had a $\delta^{13} \mathrm{C}$ value different from the reference gas. The latter was obtained from the BOC and calibrated versus VPDB at the DeltaLab. The precision and accuracy for the standards were better than $\pm 0.4 \%$.

The fractionation factor for bacterial oxidation, $\alpha_{\mathrm{ox}}$, was calculated based on values found in the literature pertaining to landfill emission studies (Table 1). Only values in the range of temperatures found during the present study were considered. The average $\alpha_{\mathrm{ox}}$ value, 1.0235, was the one adopted. Since $\alpha_{\mathrm{ox}}$ is temperature dependent, a correction had to be applied (see Table 2) using Eq. (3), which is based on Tyler et al.'s (1994) temperature dependence relationship:

$$
\alpha_{\mathrm{ox}}=\alpha_{\mathrm{ox}} \text { average }+0.00046\left[20-\mathrm{T}\left({ }^{\mathrm{o}} \mathrm{C}\right)\right] \text { or } \alpha_{\mathrm{ox}}=\alpha_{\mathrm{ox}} \text { average }+0.00046[293.15-\mathrm{T}(\mathrm{K})]
$$

Eq. (3) shows that as temperatures rise above $20^{\circ} \mathrm{C}$, lower values of $\alpha_{\mathrm{ox}}$ are obtained, which, according to Eq. (2), leads to higher oxidation efficiencies, $f_{0}$.

\section{RESULTS AND DISCUSSION}

\section{Gas concentration profiles}

The gas concentration profiles corresponding to the dates when samples were selected for stable isotope analyses are presented in Fig. 4. Four types of typical profiles were identified and are described in the following. 
Type 1 profiles (Fig. 4a, b) represent the periods during which the $\mathrm{CH}_{4}$ concentration did not change much as biogas migrated up towards the atmosphere. This means that the system was not efficient in oxidizing the entire methane loading, at least up to the top-most gas sampling point, located $0.10 \mathrm{~m}$ below the surface. However, this does not mean that oxidation was not taking place. In fact, despite the poor $\mathrm{CH}_{4}$ oxidation efficiency, a significant portion of the estimated $\mathrm{CH}_{4}$ loading was oxidized (Table 2). Above the $0.10 \mathrm{~m}$ point it is possible that further oxidation may have taken place, but no monitoring was made to verify that.

Type 1 profiles can be associated with several factors affecting aeration of the substrate, including high degrees of water saturation, $S_{w}$, (and thus a decrease in air-filled porosity) and high upward biogas fluxes. The hypothesis of high $S_{w}$ near the surface for Type 1 profiles do not hold, because $S_{w}$ values were similar to those found in other situations where the oxidation efficiency was high (discussed below). The observed sharp decrease in $\mathrm{N}_{2}$ near the surface (Fig. 4a,b) suggests poor aeration and points to high upward biogas loading as an important factor contributing to give the profile its shape. As far as evaluation of aeration is concerned, $\mathrm{N}_{2}$ is a better indicator than $\mathrm{O}_{2}$ because it is neither consumed by oxidation near the surface nor by soil respiration. Although we did not have any control on the magnitude of the $\mathrm{CH}_{4}$ loading (the GDL sits directly on the waste mass), an estimate of the loading was made (see Table 2) based on loading data and the $\mathrm{CH}_{4}$ oxidation efficiency of the system, $f_{0}$. The latter is given by stable isotope data, which is presented and commented below.

With Type 2 (Fig. 4 c, d) the $\mathrm{CH}_{4}$ concentration didn't change up to a depth of approximately $0.4 \mathrm{~m}$, and then decreased slightly, with the $\mathrm{CH}_{4}$ concentration at the uppermost sampling point $(0.1 \mathrm{~m})$, remaining high. The observed deeper penetration of $\mathrm{N}_{2}$ associated with Type 2 profiles is an indication that the upper part of the substrate was better aerated, which should favour oxidation. The surface flux obtained on Sept $24^{\text {th }}$ was still high but much lower than in the case of Type 1, which was consistent with the deeper penetration of $\mathrm{N}_{2}$. However, the quite high flux obtained in all surface measurements made at PMOB-1 on June $26^{\text {th }}$ (Table 2) is bewildering. Two possible explanations can be offered: the first is that the locations of the profiles do not correspond exactly to the locations where surface flux measurements were conducted. In this case, the static chamber may have been placed exactly above a micro-fissure that was impossible to detect visually; as a consequence, a very high flux was measured. A second plausible cause for the high flux on June $26^{\text {th }}$ is related to unequal moisture distribution within the substrate, a phenomena associated with unsaturated flow of water through the cover, which may lead to heterogeneous (or non uniform) gas distribution within the PMOBs (Cabral et al. 2007). This, combined with potential preferential flow, may also explain the high flux measured. 
While oxidation may be taking place near the surface, dilution of the pore gas also contributes to the decrease in $\mathrm{CH}_{4}$ concentration from 0.1 to the surface. In addition, part of the incoming $\mathrm{O}_{2}$ is consumed by soil respiration.

Type 3 (Fig. 4e, f, g) corresponds to profiles where a steady decrease in $\mathrm{CH}_{4}$ concentration was observed almost throughout the substrate (note that the substrate for PMOB-3B starts at the $0.3 \mathrm{~m}$ mark; Fig. 4g), although the concentrations of $\mathrm{CH}_{4}$ at a depth of $0.1 \mathrm{~m}$ were still not negligible. One is tempted to associate these types of profiles with favourable conditions leading to a much deeper penetration of atmospheric air (see $\mathrm{N}_{2}$ profiles in Fig. $4 \mathrm{e}, \mathrm{f}, \mathrm{g})$, such as low degrees of saturation or increasing atmospheric pressure. The relatively high surface flux obtained on June $11^{\text {th }}$ is also puzzling, given the quite effective penetration of atmospheric air. Finally, given the greater potential for dilution near the surface and the surprisingly low $\mathrm{O}_{2}$ concentration below 0.1 to $0.2 \mathrm{~m}$ (in part due to respiration), stable isotope data become an important tool to evaluate the actual oxidation efficiency of systems identified by these types of profiles.

The last one, Type 4 (Fig. 4h), represents profiles observed in PMOB-1 for nearly two consecutive weeks of dry weather, during the summer of 2007. Evidence of dryer substrate is found in the value of $S_{w}$ at the bottom of the substrate, which is the lowest of all shown in Fig. 5 for PMOB-1 $\left(S_{w}=82.1 \%\right)$. In addition, the surface flow was below detectable limits and the nearly vertical $\mathrm{N}_{2}$ concentration profile (Fig. $4 \mathrm{~h}$ ) clearly indicates that the substrate was well aerated throughout its depth. The $\mathrm{CH}_{4}$ concentration, which was already relatively low $(28.8 \%)$ at $0.82 \mathrm{~m}$, decreased to quite low levels $(\sim 1 \%)$ at 0.3 to $0.4 \mathrm{~m}$. The relatively high $\mathrm{O}_{2}$ concentration at $0.6 \mathrm{~m}$ may have resulted from a measurement error; otherwise, the Authors cannot find any other plausible interpretation for this odd datum. The quite low concentrations of $\mathrm{CH}_{4}$ near the surface cannot be associated with oxidation alone. As mentioned previously, soil respiration and dilution of the pore gas also have to be considered and stable isotope results become a useful tool to evaluate the extent of oxidation. Although it is impossible to verify (using either our data or site records), the $\mathrm{CH}_{4}$ loading might have been quite low during the two-week period during which the Type 4 profile was obtained, allowing for the large extent of diffusive ingress of atmospheric air.

According to Chanton and Liptay (2000), and Stern et al. (2007), the optimum soil temperature for $\mathrm{CH}_{4}$ oxidation appears to be from $25{ }^{\circ} \mathrm{C}$ to $30{ }^{\circ} \mathrm{C}$. With the exception of the profile obtained in PMOB-3B (Fig. 5g), where temperatures remained in the vicinity of $30^{\circ} \mathrm{C}$, for all the other dates for which sampling for isotope analyses was performed, the temperatures remained in the vicinity of $20^{\circ} \mathrm{C}$. The lowest air temperature during the monitoring period was approximately $15^{\circ} \mathrm{C}$ and the highest reached approximately $30^{\circ} \mathrm{C}$. For all sampling times, the air temperature (shown in Fig. 5 as the value at the surface) was always slightly lower than the temperature at $0.1 \mathrm{~m}$. 


\section{$\delta^{13} \mathrm{C}$ Values and oxidation efficiencies}

Table 2 presents the results of stable isotope analyses for the 4 types of profiles. The $\delta^{13} \mathrm{C}$ value of methane from the waste mass $\left(\delta_{\mathrm{A}}\right)$, or baseline $\mathrm{CH}_{4}$ concentration value, was obtained by applying Eq. (1) to stable isotope data obtained at $0.82 \mathrm{~m}$ depth, even in the case of PMOB-3B.

When the $\mathrm{CH}_{4}$ oxidation efficiency was calculated from the baseline $(0.82 \mathrm{~m})$ to the surface, $\delta_{\mathrm{E}}$ corresponded to the $\delta^{13} \mathrm{C}$ value obtained from samples collected during static chamber tests (thus at the surface). When the oxidation efficiency was calculated from $0.82 \mathrm{~m}$ to the top-most gas probe $(0.10 \mathrm{~m}$ from the surface $), \delta_{\mathrm{E}}$ corresponded to the $\delta^{13} \mathrm{C}$ value obtained at $0.10 \mathrm{~m}$. The same applied to the oxidation efficiencies related to $0.05 ; 0.30$ and $0.40 \mathrm{~m}$ depths; $\delta_{\mathrm{E}}$ corresponded to the $\delta^{13} \mathrm{C}$ value obtained at these depths, respectively.

The interpretation of the results of stable isotopes is made in two phases: the first deals with $f_{0}$ calculated using the $\delta^{13} \mathrm{C}$ obtained at the $0.05,0.1,0.3$ and $0.4 \mathrm{~m}$ depths; the second will discuss the $f_{0}$ values obtained from samples collected during static chamber tests, i.e. at the surface.

\section{Oxidation efficiency based on stable isotope probing of soil gas profiles}

Type 1 and Type 2 profiles exhibited low values of $f_{0}$, because of the estimated high biogas loadings and poor aeration of the substrate. In the case of Type 3 profiles, the oxidation efficiencies were much higher and reached $88.7 \%$ at 0.1 in PMOB-3B (the oxidation efficiency obtained at $0.05 \mathrm{~m}$ is discussed later in the text). It appears that oxidation was already detectable at the base of the $0.3-\mathrm{m}$ thick substrate, where $f_{0}=18.4 \%$. In addition, the $\mathrm{CH}_{4}$ concentration at $0.82 \mathrm{~m}$ (depth at which $\delta_{\mathrm{A}}$ was taken) was lower than usual baseline values of raw landfill biogas. It can be deduced that, if $f_{0}$ were to be calculated using the average $\delta_{\mathrm{A}}$ in the present study $\left(-57.9 \%\right.$ ), the $f_{0}$ value would have been 100\%; in other words, the system in PMOB-3B for Sept 24, 2007, would have been 100\% efficient.

Methane oxidation efficiency calculations for PMOB-3B can also be made based on mass balance calculations, and then compared to stable isotope analyses (e.g. Powelson et al. 2007). In the present study, mass balance calculations were made using loading and surface flux measurements for PMOB-3B only (loading data were not available for PMOB-1 since it sits directly on the waste mass). For the sole result from PMOB-3B (Sept. $24^{\text {th }}$ ), the surface flux was $4.31 \mathrm{~m}^{-2} \mathrm{~h}^{-1}$ (Table 2), whereas the $\mathrm{CH}_{4}$ loading was in the vicinity of $15 \mathrm{l} \mathrm{m}^{-2} \mathrm{~h}^{-1}$, which results in a $\mathrm{CH}_{4}$ oxidation efficiency of $70 \%$. The $f_{0}$ obtained using stable isotope was equal to $55.6 \%$ (data is taken from surface (chamber test) measurements. Several factors can explain this discrepancy, including: 1 ) the sensitivity of $f_{0}$ to slight changes in the isotopic fractionation factor for bacterial oxidation, $\alpha_{\mathrm{ox}}$; [for example, adoption of $\left(\alpha_{o x}-\sigma\right)=$ 
1.0188 (see Table 3, whose results are discussed later in the text), instead of the average value considered; i.e. $\alpha_{o x}=$ 1.0235) would have led to $f_{0}=68.9 \%$ (Table 3 ), i.e. practically the same oxidation efficiency obtained by mass balance]; 2) uncertainties related to the static chamber method; and 3) uncertainties related to mass flow meter readings (the values read were close to the margin of error of the equipment). Powelson et al. (2007) attributes the discrepancy in part to oxidation of a portion of the inflow gas. Irrespective of this discrepancy, the results of the stable isotope analysis did help confirm that oxidation was occurring and that the system was very efficient in reducing $\mathrm{CH}_{4}$ emissions.

Despite deeper penetration of atmospheric air within the substrate of PMOB-1 than within PMOB-3B for Type 3 profiles, as evidenced by the more abrupt $\mathrm{N}_{2}$ profiles within the substrate of PMOB-1 (Fig. $4 \mathrm{f}, \mathrm{g}$ and $\mathrm{h}$ ), the values of $f_{0}$ obtained at $0.1 \mathrm{~m}$ for PMOB-1 (45.1\% and 64.4\%, for June $11^{\text {th }}$ and Aug. $20^{\text {th }}$, respectively; Table 2) are lower than that obtained for PMOB-3B $(88.7 \%$ at $0.1 \mathrm{~m})$. In addition, the $\mathrm{CH}_{4}$ surface flux on Aug. 20 ${ }^{\text {th }}$ at PMOB-1, profile 1 is four times lower than the flux measured on Sept. $24^{\text {th }}$ on the surface of PMOB-3B (Table 2). The higher temperatures existing in PMOB-3B on Sept $24^{\text {th }}$ (Fig. 5g) might be partly responsible for this. According to the $\mathrm{Q}_{10^{-}}$ rule, reaction rates increase by approximately a factor of 2 for every $10{ }^{\circ} \mathrm{C}$ increase in temperature. This given, temperatures in the vicinity of $30^{\circ} \mathrm{C}$ in $\mathrm{PMOB}-3 \mathrm{~B}$ may have induced higher $\mathrm{CH}_{4}$ oxidation rates than the temperatures in the vicinity of $20^{\circ} \mathrm{C}$ found in PMOB-1. Moreover, as previously discussed, temperature also has an important effect on the value of $\alpha_{o x}$, thus on $f_{0}$ (e.g. Coleman et al. 1981; Chanton and Liptay 2000). This also justifies why the values of $\alpha_{o x}$ in Table 2 (fourth column from the right) that were used in the calculation of $f_{0}$ were adjusted to consider the temperatures prevailing during sampling. In PMOB-3B there was a depletion (decrease in $\delta^{13} \mathrm{C}$ ) between 0.1 and $0.05 \mathrm{~m}$, which may be associated, at least in part, with one of the three phenomena that led to loss of enrichment in $\mathrm{CH}_{4}-\delta^{13} \mathrm{C}$ values measured at the surface (see discussion in the next subsection).

As far as the Type 4 profile is concerned, on July $17^{\text {th }}$ the $\mathrm{CH}_{4}$ concentrations at depths reaching $0.4 \mathrm{~m}$ were already rather low and the oxidation efficiency in PMOB-1 reached $89.7 \%$ at $0.1 \mathrm{~m}$ (Table 2). A significant portion of the oxidation occurred within the bottom-most $0.4 \mathrm{~m}$ of substrate, with $f_{0}=69.1 \%$ at $0.4 \mathrm{~m}$. It can be observed that the temperatures within the substrate (Fig. 5h) were not as high as those measured within PMOB-3B (Fig. 5g), indicating that other factors contributed to the high $f_{0}$. Indeed, excellent aeration of the substrate, as evidenced by the nearly vertical $\mathrm{N}_{2}$ profile (Fig. $4 \mathrm{~h}$ ) helps to explain the high oxidation efficiency obtained.

Following the same line of thought used for the interpretation of the data from PMOB-3B, if a typical $\delta_{\mathrm{A}}$ were used (-57.9\%o, rather than $-56.0 \%$ ), the $\mathrm{CH}_{4}$ oxidation efficiency of PMOB-1, calculated using Eq. (2), would be 
$99 \%$ at a depth of $0.1 \mathrm{~m}$, i.e. the system could be considered $100 \%$ efficient for the two-weeks represented by the profile obtained on July 17, 2007.

On July $17^{\text {th }}$, the $\mathrm{CH}_{4}$ concentration at $0.82 \mathrm{~m}$ depth $(28.8 \%)$ was much lower than the typical value observed on the investigated landfill biogas ( $58 \%)$. This indicates that some oxidation was possibly occurring within the gas distribution layer. Gebert and Gröngröft (2006) also showed high $\mathrm{CH}_{4}$ oxidation rates obtained with coarse, purely mineral material in a biofiltre experiment. In the present case, dilution played an important role. Indeed $\mathrm{N}_{2}$ penetrated very deep down and its concentration at the interface with the GDL was as high as $36.7 \%$. According to the data presented in Table 2, the $\delta^{13} \mathrm{C}$ value (- 56.0\%) was in the lower range of values recorded for raw biogas in this study. If a typical $\delta^{13} \mathrm{C}$ value of the anoxic zone $\left(\delta_{\mathrm{A}}\right)$ were used, the oxidation efficiency at the base of the substrate would be in the vicinity of $10 \%$, showing that some oxidation might be occurring within the GDL. However, this oxidation is limited by the lack of $\mathrm{O}_{2}$, which was mostly depleted near the surface. In conclusion, the low $\mathrm{CH}_{4}$ concentration at the base of the cell is mainly a result of dilution with atmospheric components.

\section{Oxidation efficiency based on stable isotope probing of static chambers}

The data in Table 2 show that there is a clear loss of enrichment in $\mathrm{CH}_{4}-\delta^{13} \mathrm{C}$ values between $0.1 \mathrm{~m}$ and the surface, i.e. the values become more negative, except for PMOB1-P4, on Sept. $24^{\text {th }}$, when it remained almost unaltered. In the case of the representative Type 4 profile, there is an almost entire loss of enrichment. According to Chanton et al. (2008), there are three possible mechanisms causing the loss of enrichment: diffusive fractionation, bypass mixing, and differential flow path oxidation. The first relates to the faster migration of ${ }^{12} \mathrm{CH}_{4}$ (De Visscher et al. 2004), which causes an enrichment $\mathrm{CH}_{4}-\delta^{13} \mathrm{C}$ in the sub-surface $\left({ }^{13} \mathrm{CH}_{4}\right.$ is left behind), thus a consequent loss of enrichment at the surface (greater ${ }^{12} \mathrm{CH}_{4}$ concentration). The second reason, bypass mixing, results from a mix of oxidized and non-oxidized biogas at the surface. The non-oxidized biogas would reach the surface through macropores or fissures, thereby bypassing, at least in part, contact with methanotrophs. If the gas probes do not intercept the macropores or fissure, a higher (or less negative) $\delta^{13} \mathrm{C}$ is obtained. Finally, according to Chanton et al. (2008), differential flow path oxidation is related to situations where there is complete oxidation of $\mathrm{CH}_{4}$ in a particular flow path, whereas in another flow path $\mathrm{CH}_{4}$ is not or is much less oxidized. The first, a "dead end" flow, does not contribute to the same extent to the overall oxidation efficiency. Chanton et al. (2008) hypothesize that the surface values would constitute a low limit for $\mathrm{CH}_{4}$ oxidation efficiency estimation, whereas the values obtained from gas probes would constitute un upper limit. 
The above mentioned hypotheses were neither verified, nor investigated in detail within the scope of the present study. One idea to investigate what is actually happening would be to improve the methodology to sample very near the surface (less than $0.05 \mathrm{~m}$ ). Given the heterogeneities within normal final covers, and the possibility of preferential flow (such as alluded to by Chanton et al. (2008)), one might consider taking several shallow samples over an extended area, in a very short period of time (preferably as simultaneously as possible), in order to obtain a representative set of values. Again, this procedure was not tested within the scope of the present paper, but will be considered for future work.

\section{Considerations about the influence of the adopted $\alpha_{o x}$ on $f_{0}$}

Since $\alpha_{\text {oxs }}$ was calculated based on values from previous studies (Table 1), we performed a sensitivity analysis of $f_{0}$ to variations in $\alpha_{\mathrm{ox}} \pm$ standard deviation $(\sigma)$ of the data presented in Table 1 . The results presented in Table 3 show that with $\alpha_{\mathrm{ox}}+\sigma$ ), which represents a meagre $0.5 \%$ variation in $\alpha_{\mathrm{ox}}$, the values of $f_{0}$ decrease by an average of $16 \%$. When $\alpha_{\mathrm{ox}}-\sigma$ is adopted, $f_{0}$ increases by an average of $24 \%$. The increase or decrease in efficiency leads to an equivalent change in the magnitude of both the estimated $\mathrm{CH}_{4}$ loading and the estimated rate of $\mathrm{CH}_{4}$ removal

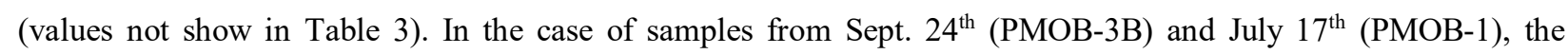
adoption of $\alpha_{o x}-\sigma$ resulted in oxidation efficiencies greater than $100 \%$, which is impossible (maybe $\alpha_{\mathrm{ox}}-\sigma$ is too low a value for the isotopic fractionation factor). Overall, it appears from this analysis that slight variations in the adopted isotopic fractionation factor have a measurable influence on the $\mathrm{CH}_{4}$ oxidation efficiency of the cover system.

\section{Considerations concerning the adopted fractionation factor, $\alpha_{\text {trans }}$}

As discussed previously, the consideration of $\alpha_{\text {trans }}$ equal to 1.0 is reasonable insofar as gas transport is dominated by advection. In the case of PMOB-3B, the biogas loading was high $\left(\sim 15 \mathrm{l} \mathrm{m}^{-2} \mathrm{~h}^{-1}\right)$ with the diffusive flux representing less than $2 \%$ of this loading. The diffusive flux was determined using Fick's first law, the average concentration gradient between the bottom and the top of the PMOB and the diffusion coefficient of the material (data not presented). Therefore, the assumption $\alpha_{\text {trans }}=1$ seems plausible (see also Background section). With respect to PMOB-1, loadings could not be controlled because the GDL sits directly over the waste mass. It is thus necessary to rely on surface flux measurements, which, as shown in Table 2, are also high, with the exception of the fluxes obtained on Aug. $20^{\text {th }}$ and July $17^{\text {th }}$. 
For the latter two dates, a closer look into this issue would be necessary. For example, Rannaud et al. (2008) showed that a pressure differential ( $\Delta \mathrm{p}_{-}$bar) equal to $0.05 \mathrm{kPa}$ (equivalent to a $5 \mathrm{~mm}$ column of water) was required to reproduce a $\mathrm{CH}_{4}$ concentration profile obtained in the field during the summer of 2006, using the TOUGH2-LGM simulator (Nastev 1998). This profile showed a marked reduction in $\mathrm{CH}_{4}$ concentrations near the surface, as is the case for the profiles obtained on Aug. $20^{\text {th }}$ and July $17^{\text {th }}$. With such a low, yet realistic pressure differential (the values of $\Delta \mathrm{p} \_$bar a few hours before sampling were in the vicinity of $0.05 \mathrm{kPa}$; data not presented), and considering the values of the degree of water saturation existing in PMOB-1 on the same dates $\left(S_{w} \approx 70 \%\right)$, Rannaud et al. (2008) obtained the diffusive and advective fluxes using TOUGH2-LGM. The diffusive flux $\left(\sim 0.141 \mathrm{~m}^{-2} \mathrm{~h}^{-1}\right)$ was nearly one order of magnitude higher than the advective flux. Under such conditions, the assumption of $\alpha_{\text {trans }}=1$ would have led to an underestimation of the oxidation efficiency should stable isotopes be used to calculate it (De Visscher et al. 2004). No further investigation into this issue was performed.

\section{Summary and concluding remarks}

Stable isotope analyses were performed in order to evaluate the biotic methane oxidation efficiencies of two experimental biocovers installed at the St-Nicéphore landfill, Quebec, Canada. Methane concentration profiles in the substrate were divided into four types, varying from profiles showing almost no to limited decrease in the vertical $\mathrm{CH}_{4}$ concentration (Types 1 and 2) to profiles where there is a clear decrease in $\mathrm{CH}_{4}$ concentration near the surface (Type 3), or even deep inside it (Type 4).

The sharp decrease in $\mathrm{CH}_{4}$ concentration observed near the surface in all cases, and deeper down in other cases, cannot guarantee that oxidation was the only phenomenon taking place. Indeed, part of the decrease was due to atmospheric air penetration, thus dilution of the pore gas. Stable isotope analyses became a useful tool to calculate oxidation efficiency in a system where soil respiration competes for the same incoming $\mathrm{O}_{2}$.

The results of stable isotope analyses showed that the substrates of the two PMOBs were indeed able to promote $\mathrm{CH}_{4}$ oxidation. This was evidenced by the enrichment in the ${ }^{13} \mathrm{C}$ isotope in the upward migrating biogas, due to preferential use of the ${ }^{12} \mathrm{C}$ isotope by methanotrophic bacteria. Oxidation efficiencies calculated for a depth of $0.1 \mathrm{~m}$ from the surface varied from 2.9 to $89.7 \%$ in PMOB-1, and was equal to $88.7 \%$ for a representative profile of a relatively dry period in PMOB-3B. In some cases, the amount of $\mathrm{CH}_{4}$ oxidized was high, but the loading was also too high, resulting in poor oxidation efficiency, in spite of the higher absolute rate of methane removal. 
The analysis of the results shows that one single factor cannot explain the high or low oxidation efficiencies obtained. Indeed, a set of factors governed the response of the system. For example, despite the relatively low degree of saturation prevailing near the surface in most of the situations investigated, poor aeration of the substrate was observed in certain cases, leading to quite low efficiencies (profiles of the Types 1 and 2). It is impossible to affirm that poor aeration was partly caused by high upward biogas fluxes, since loading could not be controlled in PMOB-1. However, the assumption of high loadings seems to hold for Type 1 and Type 2 profiles, given the fact that $\mathrm{CH}_{4}$ oxidation remained very low and surface fluxes were the highest.

Another factor that could partly explain high or low efficiencies is the temperature within the substrate. In the present study, despite the fact that it was more than $10^{\circ} \mathrm{C}$ lower within the profile of PMOB-1 on July $17^{\text {th }}$ (Fig. 5h) than within the profile of PMOB-3B on Sept. $24^{\text {th }}$ (Fig. $5 \mathrm{~g}$ ), the oxidation efficiencies calculated at $0.1 \mathrm{~m}$ were quite high for both $(89.7 \%$ and $88.7 \%$, respectively). In this case, the higher surface flow in PMOB-3B seems to be limiting $\mathrm{O}_{2}$ penetration, while the non-detected flow near the surface of PMOB-1 and deep penetration of $\mathrm{N}_{2}$ indicated that oxidation was being favoured within PMOB-1 on July $17^{\text {th }}$ (Fig. 4g).

A loss of enrichment in $\mathrm{CH}_{4}-\delta^{13} \mathrm{C}$ values was observed between the upper-most probe (located $0.1 \mathrm{~m}$ below the surface) and the surface. Chanton et al. (2008) refer to four mechanisms that could be at the origin of such behaviour. However, the actual causes for the loss of enrichment were not investigated in detail within the scope of the present study. It is suggested to improve the methodology of sampling very near the surface and develop a field program whereby several shallow samples would be collected over an extended area and in a very short period of time. With this extended dataset, one might be able to identify more clearly the reasons for the loss of oxidation efficiency near the surface.

Due to a number of reasons, the oxidation efficiencies obtained in this study have to be considered as indicators of the real efficiencies. One of these reasons is that the actual fractionation factor values were not determined specifically for the study. A sensitivity analyses of $f_{0}$ to variations in $\alpha_{o x}$ showed that slight variations in the adopted $\alpha_{o x}$ has a measurable influence on the oxidation efficiency of the system. Subsequently, efficiency analyses based on stable isotope probing have to be interpreted with adequate caution. Another reason for considering the values of $f_{0}$ as indicators is that $\alpha_{o x}$ is directly influenced by soil temperature; the latter being a parameter that continuously changes. For a more precise evaluation of oxidation efficiencies, a study considering both short and long term variations of $f_{0}$ would be recommended.

\section{Acknowledgements}


The Authors wish to acknowledge the financial support provided by the National Science and Engineering Research

Council of Canada, WM (Waste Management) Canada and the BIOCAP Canada Foundation (Strategic grant \# GHG 322418-05). We also are grateful to Ms Anna Smirnoff (DeltaLab, Geological Survey of Canada, GSC-Quebec).

\section{References}

Abichou, T., Powelson, D., Chanton, J., Escoriaza, S., and Stern, J. 2006a. Characterization of methane flux and oxidation at a solid waste landfill. Journal of Environmental Engineering, 132(2): 220-228.

Abichou, T., Chanton, J., Powelson, D., Fleiger, J., Escoriaza, S., Lei, Y., and Stern, J. 2006b. Methane flux and oxidation at two types of intermediate landfill covers. Waste Management, 26(11): 1305-1312.

Boeckx, P., and Van Cleemput, O. 2000. Methane oxidation in landfill soils. In Trace gas emissions and plants. Kluwer, The Netherlands. pp. 197-213.

Boeckx, P., Van Cleemput, O., and Villaralvo, I. 1996. Methane emission from a landfill and the methane oxidizing capacity of its covering soil. Soil Biology and Biochemistry(28): 1397-1405.

Bogner, J., Meadows, M., and Czepiel, P. 1997. Fluxes of methane between landfills and the atmosphere: natural and engineered controls. Soil Use and Management, 13: 268-277. .

Bogner, J.E., and Matthews, E. 2003. Global Methane Emissions from Landfills : New Methodology and Annual Estimates 1980-1996. Global Biogeochemical Cycles, 17(2): 1065-1083.

Börjesson, G., Samuelsson, J., and Chanton, J. 2007. Methane Oxidation in Swedish Landfills Quantified with the Stable Carbon Isotope Technique in Combination with an Optical Method for Emitted Methane. Environ. Sci. Technol., 41: $6684-6690$.

Cabral, A.R., Parent, S.-É., and El Ghabi, B. 2007. Hydraulic aspects of the design of a passive methane oxidation barrier. In 2nd BOKU Waste Conf. Edited by P. Lechner. Vienna. April 16-19, pp. 223-230.

Chanton, J.P., and Liptay, K. 2000. Seasonal Variation in Methane Oxidation in a Landfill Cover Soil as Determined by an In situ Stable Isotope Technique. Global Biogeochem. Cycles, 14: 51-60.

Chanton, J.P., Rutkowski, C.M., and Mosher, B. 1999. Quantifying methane oxidation from landfills using stable isotope analysis of downwind plumes. Environmental Science and Technology, 33(21): 3755-3760.

Chanton, J.P., Powelson, D.K., Abichou, T., and Hater, G. 2008. Improved field methods to quantify methane oxidation in landfill cover materials using stable carbon isotopes. Environmental Science and Technology, 42(3): $665-670$.

Coleman, D.D., Risatti, J.B., and Schoell, M. 1981. Fractionation of carbon and hydrogen isotopes by methaneoxidizing bacteria. Geochim. Cosmochim. Acta, 45: 1033-1037.

Czepiel, P., Mosher, B., Crill, P., and Harriss, R. 1996. Quantifying the effect of oxidation on landfill methane emissions. Journal of Geophysical Research, 101(11): 16721-16729.

Czepiel, P.M., Shorter, J.H., Mosher, B., Allwine, E., McManus, J.B., Harriss, R.C., Kolb, C.E., and Lamb, B.K. 2003. The influence of atmospheric pressure on landfill methane emissions. Waste Management, 23(7): 593-598.

De Visscher, A., De Poureq, I., and Chanton, J. 2004. Isotope fractionation effects by diffusion and methane oxidation in landfill cover soils. Journal of Geophysical Research, 109(D18): 8 pp. 
Fécil, B., Héroux, M., and Guy, C. 2003. Development of a method for the measurement of net methane emissions from MSW landfills. In 9th International Waste Management and Landfill Symposium, October 6-10, Italy. (CD-Rom).

Gebert, J., and Gröngröft, A. 2006. Performance of a passively vented field-scale biofilter for the microbial oxidation of landfill methane. Waste Management, 26(4): 399-407.

Hilger, H., and Humer, M. 2003. Biotic Landfill Cover Treatments for Mitigating Methane Emissions. Environmental Monitoring and Assessment, 84(1): 71-84.

Humer, M., and Lechner, P. 1999. Alternative approach to the elimination of greenhouse gases from old landfills. Waste Management Research(17): 443-452.

IPCC 2001. Climate Change 2001: The Scientific Basis. Contribution of Working Group I to the Third Assessment Report of the Intergovernmental Panel on Climate Change, IPCC, Cambridge.

IPCC 2007. Climate change 2007: Mitigation. Contr. Working Group III to the $4^{\text {th }}$ Assess Report of the IPCC. In Intergovernmental Panel on Climate Change, Cambridge, United Kingdom and New York, NY, USA.

Jugnia, L.B., Cabral, A.R., and Greer, C.W. 2008. Biotic methane oxidation within an instrumented experimental landfill cover. Ecological Engineering, Vol 33(2): 102-109.

Liptay, K., Chanton, J., Czepiel, P., and Mosher, B. 1998. Use of stable isotopes to determine methane oxidation in landfill cover soils. Journal of Geophysical Research, 103(D7): 8243-8250.

Nastev, M. 1998. Modeling Landfill Gas Generation and Migration in Sanitary Landfills and Geological Formations. Ph.D. Thesis, Université Laval, 373 p.

Powelson, D.K., Chanton, J.P., and Abichou, T. 2007. Methane oxidation in biofilters measured by mass-balance and stable isotope methods. Environmental Science and Technology, 41(2): 620-625.

Rannaud, D., Cabral, A.R., and Allaire, S.E. 2008. Modeling Methane Migration and Oxidation in Landfill Cover Materials with TOUGH2-LGM. Water, Air and Soil Poll., 198(1): 253. 10.1007/s11270-008-9843-4।

Scheutz, C., Bogner, J., Chanton, J., Blake, D., Morcet, M., and Kjeldsen, P. 2003. Comparative oxidation and net emissions of methane and selected mon-methane organic compounds in landfill cover soils. Environ. Sci. Technol., 37: 5150-5158.

Spokas, K., Bogner, J., Chanton, J.P., Morcet, M., Aran, C., Graff, C., Moreau-Le Golvan, Y., and Hebe, I. 2006. Methane mass balance at three landfill sites: What is the efficiency of capture by gas collection systems? Waste Manage., 26: 516-525.

Stern, J.C., Chanton, J., Abichou, T., Powelson, D., Yuan, L., Escoriza, S., and Bogner, J. 2007. Use of a biologically active cover to reduce landfill methane emissions and enhance methane oxidation. Waste Management, 27(9): 1248-1258.

Tyler, S.C., Crill, P.M., and Brailsford, G.W. 1994. 13C/12C Fractionation of methane during oxidation in a temperate forest soil. Geochim. Cosmochim. Acta, 58(6): 1625-1633. 


\section{List of tables}

Table 1 - Values of $\alpha_{o x}$ found in the literature with associated soil temperature

Table 2 - Results from stable isotope analyses and oxidation efficiencies $\left(f_{0}\right)$.

Table 3 - Results of sensitivity analysis of $f_{0}$ to changes in $\alpha_{o x}$.

\section{List of Figures}

Fig. 1 - Schematic representation of the setup of PMOB-1

Fig. 2 - Schematic representation of the setp of PMOB-3B

Fig. 3 - Instrumentation of the PMOBs

Fig. 4 - Selected gas concentration profiles for which samples were taken for stable isotope analyses: (a) and (b) are of Type 1; (c) and (d) of Type 2, (e) to (g) of Type 3 and (h) of Type 4

Fig. 5 - Profiles of degree of saturation and temperature for the sampling dates 


\begin{tabular}{|c|c|c|}
\hline$\alpha_{\text {ox }}$ & Soil temperature & Reference \\
\hline 1.0140 & \multirow{3}{*}{$25^{\circ} \mathrm{C}$} & \multirow{3}{*}{ Liptay et al., (1998) } \\
\hline 1.0220 & & \\
\hline 1.0300 & & \\
\hline 1.0235 & $22^{\circ} \mathrm{C}$ & \multirow{12}{*}{ Chanton et al., (1999) } \\
\hline 1.0288 & $9^{\circ} \mathrm{C}$ & \\
\hline 1.0307 & $5^{\circ} \mathrm{C}$ & \\
\hline 1.0311 & $4^{\circ} \mathrm{C}$ & \\
\hline 1.0315 & $3^{\circ} \mathrm{C}$ & \\
\hline 1.0304 & $6^{\circ} \mathrm{C}$ & \\
\hline 1.0240 & $20^{\circ} \mathrm{C}$ & \\
\hline 1.0266 & $15^{\circ} \mathrm{C}$ & \\
\hline 1.0269 & $13^{\circ} \mathrm{C}$ & \\
\hline 1.0240 & $21^{\circ} \mathrm{C}$ & \\
\hline 1.0241 & $20^{\circ} \mathrm{C}$ & \\
\hline 1.0316 & $3^{\circ} \mathrm{C}$ & \\
\hline 1.0244 & - & Chanton et al., (2008) \\
\hline 1.0250 & $35^{\circ} \mathrm{C}$ & \multirow{2}{*}{ Chanton e Liptay (2000) } \\
\hline 1.0490 & $8^{\circ} \mathrm{C}$ & \\
\hline
\end{tabular}

Table 1 - Values of $\alpha o x$ found in the literature with associated soil temperature 


\begin{tabular}{|c|c|c|c|c|c|c|c|c|c|c|}
\hline $\begin{array}{l}\text { Type of } \\
\text { profile }\end{array}$ & $\begin{array}{c}\text { Selected } \\
\text { dates ( 2007) }\end{array}$ & $\begin{array}{l}\text { PMOB } \\
\text { (Profile) }\end{array}$ & $\begin{array}{c}\text { Surface flux } \\
\mathrm{CH}_{4}\left(\mathrm{l} \mathrm{m}^{-2} \mathrm{~h}^{-1}\right)\end{array}$ & Depth (m) & $\begin{array}{c}\text { Vol. } \mathrm{CH}_{4} \\
\text { concentr. } \\
(\%)\end{array}$ & $\begin{array}{c}\delta^{13} C \text { of } \mathrm{CH}_{4} \\
\left(\delta_{A} \text { at } 0.82 \mathrm{~m}\right) \\
(\% \mathrm{VPDB})\end{array}$ & $\begin{array}{c}\alpha_{o x} \\
\text { (corrected for } \\
\text { temper. }^{1}\end{array}$ & $f \circ(\%)$ & $\begin{array}{c}\text { Estimated } \\
\mathrm{CH}_{4} \text { loading } \\
\left(\mathbf{l ~ m}^{-2} \mathrm{~h}^{-1}\right)\end{array}$ & $\begin{array}{c}\text { Estim rate of } \mathrm{CH}_{4} \\
\text { removal } \\
\left(1 \mathrm{~m}^{-2} \mathrm{~h}^{-1}\right)\end{array}$ \\
\hline \multirow{7}{*}{1} & \multirow{3}{*}{ July $4^{\text {th }}$} & \multirow{3}{*}{$\begin{array}{l}\text { PMOB-1 } \\
\quad(\mathrm{P} 1)\end{array}$} & \multirow{3}{*}{78.2} & Surface & 4.8 & $=06.7$ & 1.0245 & 2.9 & 880.5 & 2.3 \\
\hline & & & & 0.1 & 49.8 & -57.7 & 1.0220 & 0.0 & 78.2 & 0.0 \\
\hline & & & & 0.82 & 56.0 & -57.4 & - & - & - & - \\
\hline & \multirow{4}{*}{ Sept. $24^{\text {th }}$} & \multirow{4}{*}{$\begin{array}{l}\text { PMOB-1 } \\
\quad(\mathrm{P} 4)\end{array}$} & \multirow{4}{*}{107.4} & Surface & 4.7 & -54.6 & 1.0240 & 15.0 & 126.4 & 19.0 \\
\hline & & & & 0.1 & 44.9 & -55.6 & 1.0209 & 12.2 & 122.3 & 14.9 \\
\hline & & & & 0.3 & 48.8 & -57.6 & 1.0220 & 2.7 & 110.3 & 2.9 \\
\hline & & & & 0.82 & 58.8 & -58.2 & - & - & - & - \\
\hline \multirow{7}{*}{2} & \multirow{3}{*}{ June $26^{\text {th }}$} & \multirow{3}{*}{$\begin{array}{l}\text { PMOB-1 } \\
\quad(\mathrm{P} 4)\end{array}$} & \multirow{3}{*}{458.2} & Surface & 15.7 & -56.8 & 1.0219 & 3.7 & 475.6 & 17.4 \\
\hline & & & & 0.1 & 35.1 & -54.6 & 1.0194 & 15.4 & 541.9 & 83.7 \\
\hline & & & & 0.82 & 58.2 & -57.6 & - & - & - & \\
\hline & \multirow{4}{*}{ Sept. $24^{\text {th }}$} & \multirow{4}{*}{$\begin{array}{l}\text { PMOB-1 } \\
\quad(\mathrm{P} 1)\end{array}$} & \multirow{4}{*}{24.4} & Surface & 0.3 & -55.5 & 1.0240 & 10.5 & 27.3 & 2.9 \\
\hline & & & & 0.1 & 36.5 & -52.7 & 1.0208 & 25.2 & 32.6 & 8.2 \\
\hline & & & & 0.3 & 41.2 & -52.2 & 1.0208 & 27.8 & 33.8 & 9.4 \\
\hline & & & & 0.82 & 53.6 & -58.0 & - & - & - & - \\
\hline \multirow{11}{*}{3} & \multirow{3}{*}{ June $11^{\text {th }}$} & \multirow{3}{*}{$\begin{array}{l}\text { PMOB-1 } \\
\quad(\mathrm{P} 2)\end{array}$} & \multirow{3}{*}{21.4} & Surface & - & -53.9 & 1.0248 & 22.6 & 27.7 & 6.3 \\
\hline & & & & 0.1 & 7.7 & -49.7 & 1.0217 & 45.1 & 39.0 & 17.6 \\
\hline & & & & 0.82 & 58.3 & -59.5 & - & - & - & \\
\hline & \multirow{3}{*}{ Aug. $20^{\text {th }}$} & \multirow{3}{*}{$\begin{array}{l}\text { PMOB-1 } \\
\quad(\mathrm{P} 1)\end{array}$} & \multirow{3}{*}{1.0} & Surface & 3.3 & -53.6 & 1.0263 & 13.4 & 1.2 & 0.2 \\
\hline & & & & 0.1 & 5.0 & -42.3 & 1.0231 & 64.4 & 2.8 & 1.8 \\
\hline & & & & 0.82 & 51.6 & -57.2 & - & - & - & - \\
\hline & \multirow{5}{*}{ Sept. $24^{\text {th }}$} & \multirow{5}{*}{$\begin{array}{l}\text { PMOB-3B } \\
\text { (P3) }\end{array}$} & \multirow{5}{*}{4.3} & Surface & 2.9 & -42.4 & 1.0243 & 55.6 & 9.7 & 5.4 \\
\hline & & & & 0.05 & 0.3 & -44.0 & 1.0212 & 56.4 & 9.9 & 5.6 \\
\hline & & & & 0.1 & 5.1 & -41.7 & 1.0161 & 88.7 & 38.0 & 33.7 \\
\hline & & & & 0.3 & 41.9 & -52.8 & 1.0170 & 18.4 & 5.3 & 1.0 \\
\hline & & & & 0.82 & 49.8 & -56.0 & - & - & - & - \\
\hline \multirow{4}{*}{4} & \multirow{4}{*}{ July $17^{\text {th }}$} & \multirow{4}{*}{$\begin{array}{l}\text { PMOB1 } \\
\quad(\mathrm{P} 1)\end{array}$} & \multirow{4}{*}{$\begin{array}{c}\text { Below detectable } \\
\text { limits }\end{array}$} & Surface & 0.0 & -59.6 & 1.0240 & 0.0 & \multirow{4}{*}{$\begin{array}{l}\text { Cannot be } \\
\text { estimated }\end{array}$} & \\
\hline & & & & 0.1 & 1.2 & -35.8 & 1.0225 & 89.7 & & Cannot be \\
\hline & & & & 0.4 & 3.8 & -39.9 & 1.0232 & 69.1 & & estimated \\
\hline & & & & 0.82 & 28.8 & -56.0 & - & - & & \\
\hline
\end{tabular}

${ }^{1}$ The average $\alpha_{o x}$ value adopted (based on values found in the literature pertaining to landfill emissions studies; see Table 1) is 1.0235.

Table 2 - Results from stable isotope analyses and oxidation efficiencies $\left(f_{0}\right)$. 


\begin{tabular}{|c|c|c|c|c|c|c|c|c|}
\hline $\begin{array}{c}\text { Selected } \\
\text { dates } \\
(2007)\end{array}$ & $\begin{array}{l}\text { PMOB } \\
\text { (Profile) }\end{array}$ & Depth (m) & $\begin{array}{c}\text { Surface flux } \\
\mathrm{CH}_{4}\left(\mathrm{l} \mathrm{m}^{-2} \mathrm{~h}^{-1}\right)\end{array}$ & $f \circ(\%)$ & $\begin{array}{c}f 0(\%) \\
\quad(\text { with } \\
\left.\alpha_{o x}+\sigma\right)^{1}\end{array}$ & $\begin{array}{c}\% \text { difference in } \\
\text { relation to } f_{o} \\
\text { calculated with } \alpha_{0 x}\end{array}$ & $\begin{array}{c}f o(\%) \\
\text { (with } \\
\left.\alpha_{0 x}-\sigma\right) \\
\end{array}$ & $\begin{array}{l}\% \text { difference in } \\
\text { relation to } f_{o} \\
\text { calculated with } \alpha_{o x}\end{array}$ \\
\hline \multirow[b]{2}{*}{ July $4^{\text {th }}$} & \multirow[b]{2}{*}{$\begin{array}{l}\text { PMOB-1 } \\
\text { (P1) }\end{array}$} & Surface & \multirow[b]{2}{*}{78.2} & 2.9 & 2.4 & $16.1 \%$ & 3.5 & $-23.7 \%$ \\
\hline & & $\begin{array}{c}0.1 \\
0.82\end{array}$ & & $\begin{array}{c}0.0 \\
-\end{array}$ & 0.0 & $0.0 \%$ & 0.0 & $0.0 \%$ \\
\hline \multirow{4}{*}{ Sept. $24^{\text {th }}$} & \multirow{4}{*}{$\begin{array}{l}\text { PMOB-1 } \\
\text { (P4) }\end{array}$} & Surface & \multirow{4}{*}{107.4} & 15.0 & 12.6 & $16.3 \%$ & 18.7 & $-24.2 \%$ \\
\hline & & 0.1 & & 12.2 & 10.0 & $18.3 \%$ & 15.7 & $-28.9 \%$ \\
\hline & & 0.3 & & 2.7 & 2.2 & $17.5 \%$ & 3.4 & $-27.0 \%$ \\
\hline & & 0.82 & & - & - & & - & \\
\hline \multirow{3}{*}{ June $26^{\text {th }}$} & \multirow{3}{*}{$\begin{array}{l}\text { PMOB-1 } \\
\text { (P4) }\end{array}$} & Surface & \multirow{3}{*}{458.2} & 3.7 & 3.0 & $17.6 \%$ & 4.6 & $-27.2 \%$ \\
\hline & & 0.1 & & 15.4 & 12.4 & $19.4 \%$ & 20.4 & $-31.8 \%$ \\
\hline & & 0.82 & & - & - & & - & \\
\hline \multirow{4}{*}{ Sept. $24^{\text {th }}$} & \multirow{4}{*}{$\begin{array}{l}\text { PMOB-1 } \\
\text { (P1) }\end{array}$} & Surface & \multirow{4}{*}{24.4} & 10.5 & 8.8 & $16.3 \%$ & 13.0 & $-24.2 \%$ \\
\hline & & 0.1 & & 25.2 & 20.6 & $18.3 \%$ & 32.5 & $-29.0 \%$ \\
\hline & & 0.3 & & 27.8 & 22.7 & $18.3 \%$ & 35.8 & $-29.0 \%$ \\
\hline & & 0.82 & & - & - & & - & \\
\hline \multirow{3}{*}{ June $11^{\text {th }}$} & \multirow{3}{*}{$\begin{array}{l}\text { PMOB-1 } \\
\text { (P2) }\end{array}$} & Surface & \multirow{3}{*}{21.4} & 22.6 & 19.0 & $15.9 \%$ & 27.9 & $-23.3 \%$ \\
\hline & & 0.1 & & 45.1 & 37.1 & $17.7 \%$ & 57.5 & $-27.5 \%$ \\
\hline & & 0.82 & & - & - & & - & \\
\hline \multirow{3}{*}{ Aug. $20^{\text {th }}$} & \multirow{3}{*}{$\begin{array}{l}\text { PMOB-1 } \\
\text { (P1) }\end{array}$} & Surface & \multirow{3}{*}{1.0} & 13.4 & 11.3 & $15.1 \%$ & 16.3 & $-21.7 \%$ \\
\hline & & 0.1 & & 64.4 & 53.6 & $16.9 \%$ & 80.8 & $-25.4 \%$ \\
\hline & & 0.82 & & - & - & & - & \\
\hline \multirow{5}{*}{ Sept. $24^{\text {th }}$} & \multirow{5}{*}{$\begin{array}{l}\text { PMOB-3B } \\
\text { (P3) }\end{array}$} & Surface & & 55.6 & 46.6 & $16.2 \%$ & 68.9 & $-23.9 \%$ \\
\hline & & 0.05 & & 56.4 & 46.2 & $18.1 \%$ & 72.4 & $-28.4 \%$ \\
\hline & & 0.1 & 4.3 & 88.7 & 68.7 & $22.6 \%$ & $125.2(100 \%)$ & $-12.8 \%(w / 100 \%)$ \\
\hline & & 0.3 & & 18.4 & 14.4 & $21.6 \%$ & 25.4 & $-38.1 \%$ \\
\hline & & 0.82 & & - & - & & - & \\
\hline \multirow{4}{*}{ July $17^{\text {th }}$} & \multirow{4}{*}{$\begin{array}{l}\text { PMOB1 } \\
\text { (P1) }\end{array}$} & Surface & & 0.0 & 0.0 & $0.0 \%$ & 0.0 & $0.0 \%$ \\
\hline & & 0.1 & Below detectable & 89.7 & 74.3 & $17.3 \%$ & $113.4(100 \%)$ & $-11.4 \%(w / 100 \%)$ \\
\hline & & 0.4 & limits & 69.1 & 57.5 & $16.8 \%$ & 86.5 & $-25.2 \%$ \\
\hline & & 0.82 & & - & - & & - & \\
\hline
\end{tabular}

${ }^{1}$ Average $\alpha_{o x}=1.0235 ;\left(\alpha_{o x}+\sigma\right)=1.0282 ;\left(\alpha_{o x}-\sigma\right)=1.0188 ;$ where $\sigma$ is the standard deviation (all data from Table 1)

Table 3 - Results of sensitivity analysis of $f_{0}$ to changes in $\alpha_{o x}$. 

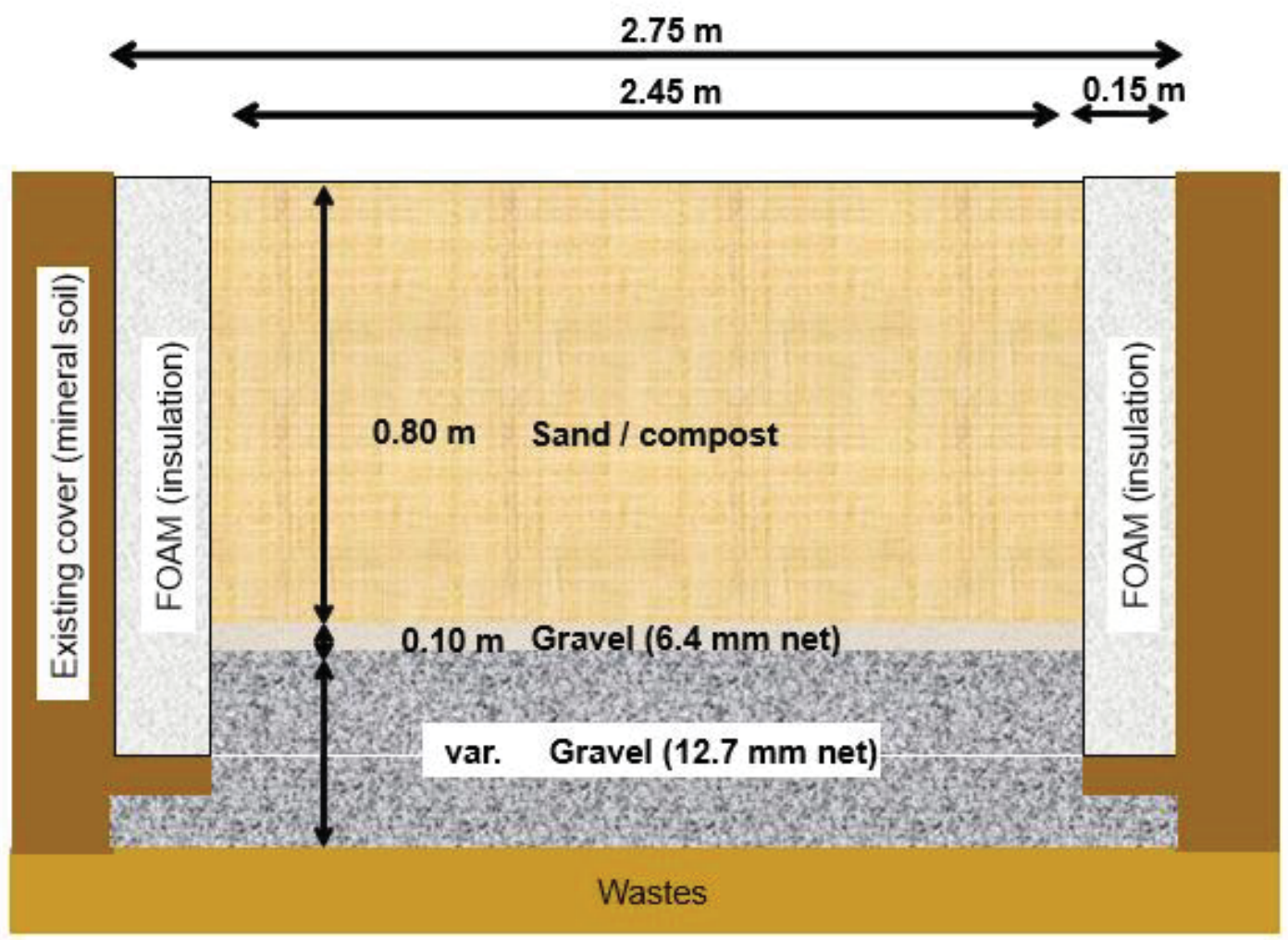

Fig. 1- Schematic representation of the setup of PMOB-1 


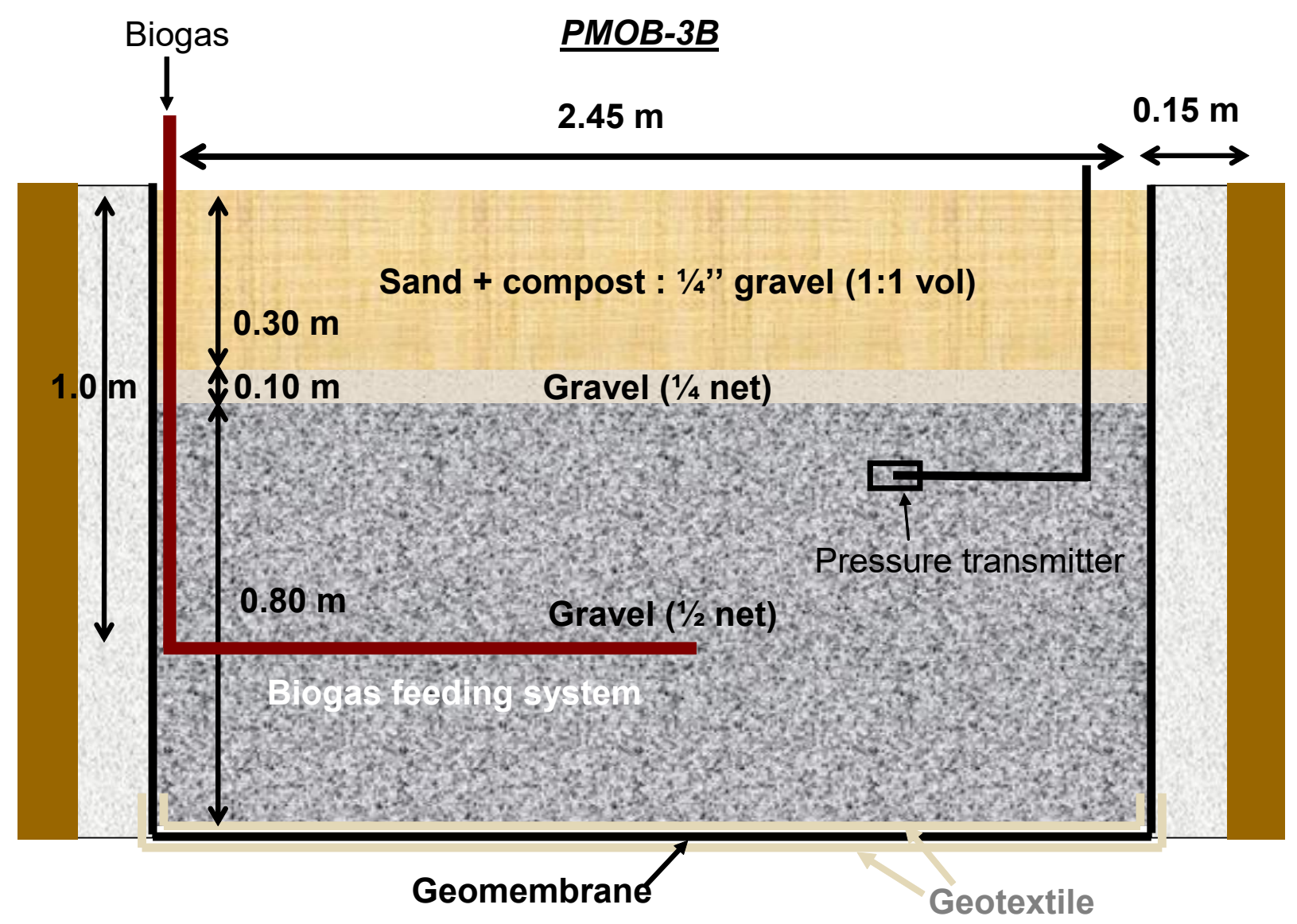

Fig. 2- Schematic representation of the setp of PMOB-3B

For PMOB-1

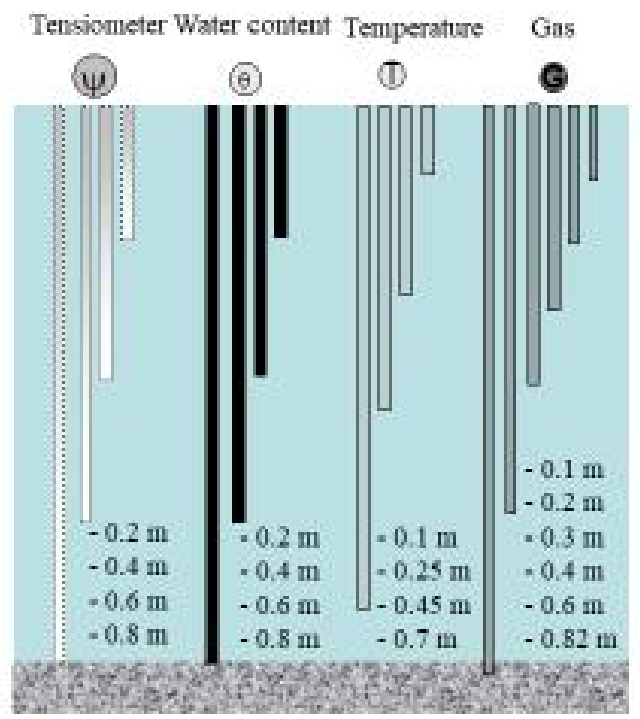

(a)
For PMOB-3B

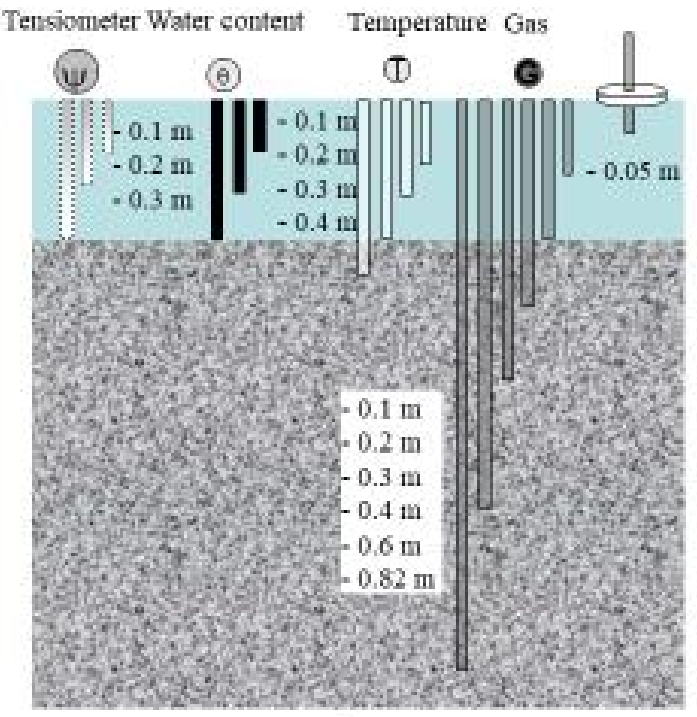

(b)

Fig. 3 - Instrumentation of the PMOBs 


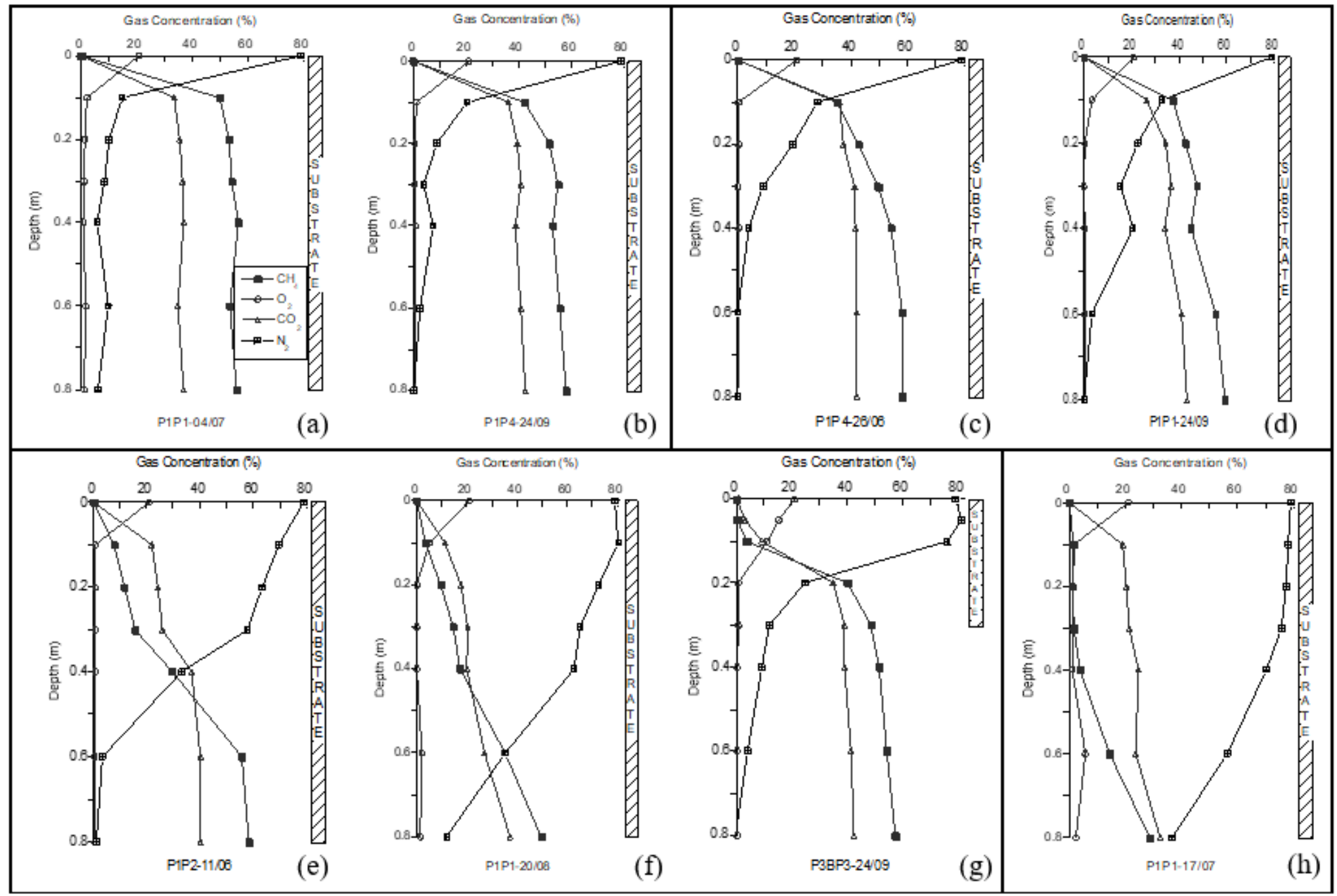

Fig. 4 - Selected gas concentration profiles for which samples were taken for stable isotope analyses: (a) and (b) are of Type 1; (c) and (d) of Type 2, (e) to (g) of Type 3 and (h) of Type 4 


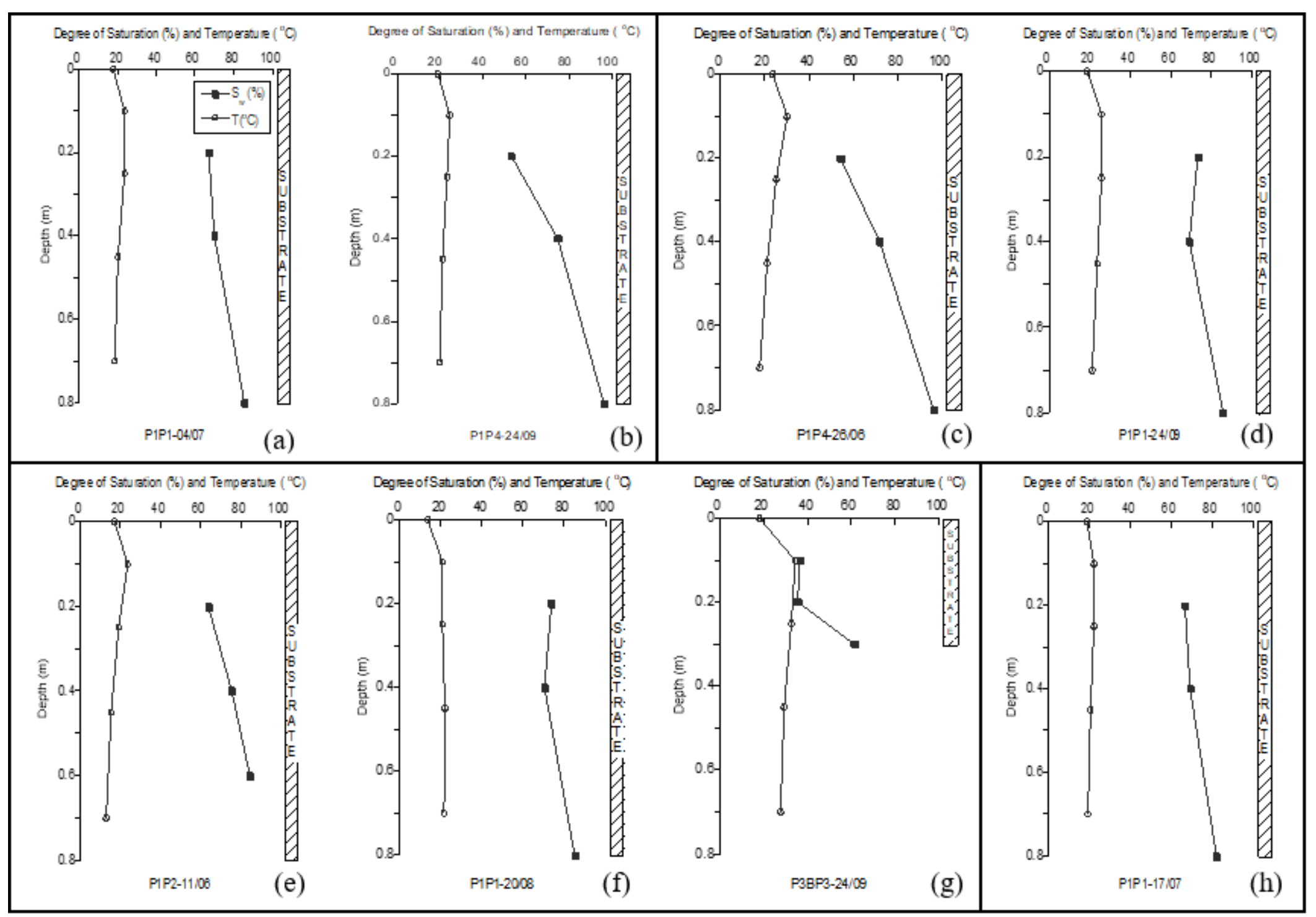

Fig. 5- Profiles of degree of saturation and temperature for the sampling dates 